\title{
THE EFFECT OF PICTURE AND PICTURE LEARNING MODELS ON THE SKILLS OF WRITING FICTION STORIES IN PRIMARY SCHOOL
}

\author{
Tia Maryani* ${ }^{*}$ Yopa Taufik Saleh ${ }^{2}$, Rahmat Permana ${ }^{3}$ \\ ${ }^{1,2,3}$ Education for Elementary School Teachers at Mubammadiyah University of Tasikmalaya Indonesia \\ 1*tyamaryani17@gmail.com \\ 2yopa_4474@yahoo.co.id \\ rahmat.pgsd@umtas.ac.id
}

\begin{tabular}{|c|c|}
\hline Article Info & Abstract \\
\hline $\begin{array}{l}\text { Historical Articles } \\
\text { Submitted: 2021-03-02 } \\
\text { Revised: 2021-06-17 } \\
\text { Issued: 2021-06-30 }\end{array}$ & $\begin{array}{l}\text { The low skill of writing fiction stories at SDN SukasariI is the background of this } \\
\text { research. The learning model used by the teacher is less varied, making it difficult for } \\
\text { students to develop ideas and ideas in writing fiction stories. The purpose of this study } \\
\text { was to determine the effect of the picture and picture learning model on writing fiction } \\
\text { skills. In this study, the method used was experimental, with a quasi experimental }\end{array}$ \\
\hline $\begin{array}{l}\text { Keywords: Picture } \\
\text { And Picture Learning } \\
\text { Model, Writing Skills, } \\
\text { Fictional Story }\end{array}$ & $\begin{array}{l}\text { sample taken in this study was the entire study population (total sampling), namely the } \\
\text { fourth grade SDN Sukasari as many as } 37 \text { students. For data collection techniques, } \\
\text { namely by interview, documentation, test bags. The tests used were pretest and posttest, } \\
\text { and data were analyzed using SPSS } 16 \text {. The data analysis technique used in this research } \\
\text { was t-test. The results of the study showed that there was an increase in the results of } \\
\text { the pretest and posttest, this is evidenced by the obtained significance value of } 0.000 \text {. In } \\
\text { accordance with the rules of decision making } 0.000<0.05 \text {, then Ho is rejected and Ha } \\
\text { is accepted. This means that the picture and picture learning model affects the skills of } \\
\text { writing fiction stories in fourth grade students of SDN Sukasari. }\end{array}$ \\
\hline
\end{tabular}

\section{INTRODUCTION}

Education in Indonesia places Indonesian as one of the areas of study taught in schools. Teaching Indonesian language must contain efforts that can bring a range of skills. These skills are closely related to the processes that underlie the mind. The more skilled a person is in speaking the brighter and clearer the way of thinking is. According to (Natsir, 2018) Language skills in the curriculum in schools usually cover four aspects, namely: (1) Listening skills; (2) speaking skills; (3) reading skills; (4) Writing skills.

Each of these skills is closely related to the other three skills in a variety of ways. In acquiring language skills, we usually go through an ordered sequence of relationships; first, in childhood, we learn to tame/listen to language, then speak; after that we learn to read and write. Listening and speaking are learned before entering school, while reading and writing are studied in school.

Writing as a language activity cannot be separated from what one gets from listening, reading, and speaking. Because it can provide valuable input for writing and help writers to develop ideas. According to (Widiastuti, 2017) writing is a language skill that aims to provide all forms of information from the author to the reader.

Writing is no different from painting (Arifian, 2018). The author has many ideas, opinions, thoughts, feelings, and obsessions that he will write about. Although technically there are criteria that can be followed, the form that will be produced is very dependent on the ability, imagination and creativity of the writer in expressing ideas. 
According to (Syarif, 2020) writing is easy as long as you have writing, willingness, sensitivity, knowledge, creativity, hard work, smart, thorough, and sincere. If writing is based on a number of things conveyed by (Rachama Putri Dinanti, Feri Ardiansah, 2020), then writing will be fun and easy to do because there is no burden to overshadow the writing process.

However, not all students like to write, even when the teacher directs students to write stories of life experiences, not a few have difficulty arranging and developing words into a sentence. In addition to the problems that exist in students, problems also exist with the teacher. In general, teachers are less skilled in writing in teaching it to students. Teachers are accustomed to using the learning model that has been applied frequently before. Therefore, a learning model is needed that supports innovative teaching and learning activities and student input. Where, the learning model is able to deliver students who are skilled in writing fictional stories, and further motivate students and make it easier for teachers in the learning process.

There are many types of fiction writing, but in this study the researcher focused more on students in writing legends or it could be said that a type of fictional prose was old prose. Legends are familiar to most students, some legends are already popular among Indonesian people. However, although some legends have been known to many people, not a few have had difficulty translating their knowledge into a written work.

Therefore, writing skills must begin to be developed in order to become more competent in writing stories. Based on interviews conducted by researchers with grade IV teachers at SDN Sukasari, the ability to write fiction stories in grade IV SDN Sukasari students is still considered less skilled and still needs to be trained so that writing skills develop. There were 20 students who scored below the KKM, 5 students scored the same as the KKM, and 12 students scored above the KKM but it was still difficult to develop their ideas.

Apart from the difficulty in developing their ideas, students also find it difficult to compose words in Indonesian. There are still students who mix their writing with their local language. This is because daily students who communicate with friends and the surrounding community are accustomed to using the local language (Sundanese language).

Seeing the difficulties in writing fiction stories in the fourth grade students of SD Negeri Sukasari, the researcher tried to do research using the picture and picture learning model. Apart from the difficulty of students writing fictional stories, researchers were also interested in testing the effectiveness of the picture and picture model that had never been applied by grade IV teachers at SDN Sukasari in learning to write fiction stories.

In supporting learning to write fiction stories for fourth grade students of SDN Sukasari, the researcher used the picture and pictrue learning model which serves to hone students' imaginations in the learning process of writing fiction stories.

\section{METHOD}

In this study, researchers used an experimental method, with a quasi experimental design. According to (Sugiono, 2015) the experimental method can be interpreted as a research method used to find the effect of certain treatments on others in controlled conditions.

A suitable design in a Quasi experimental design using the nonequivalent control group design. According to (Lin et al., 2017), the nonequivalent control group design is almost the same as the pretest-posttest control group design, only in this design the experimental group and the control group were not chosen randomly. Nonequivalent control group design is presented in Fugre 1.

\begin{tabular}{|ccc|}
\hline $\mathrm{O}_{1}$ & $\mathrm{X}$ & $\mathrm{O}_{2}$ \\
\hline $\mathrm{O}_{3}$ & & $\mathrm{O}_{4}$ \\
\hline
\end{tabular}


Infomation:

Figure 1 Nonequivalent control group design

$\mathrm{O}_{1}=$ The pretest value of the treated group (experiment)

$\mathrm{O}_{2}=$ The posttest value of the treated group (experiment)

$\mathrm{O}_{3}=$ Prestest value of the untreated group (control)

$\mathrm{O}_{4}=$ The posttest value of the untreated group (control)

$X=$ Treatment

The problem examined in this study is the lack of skills of grade IV SDN Sukasari students in writing stories. By using the experimental method (Ocampo \& Delgado, 2014) the researcher divided several students into two groups, namely the control group and the experimental group. This is done to determine the effect of the learning model used.

The population in this study were all fourth grade students at SDN Sukasari. The sample taken was the entire study population (total sampling) (Ngobolo et al., 2012), namely class IV SDN Sukasari, which amounted to 37 students. When the research was carried out, the sample of 37 students was divided into two classes using a sampling technique, namely a sampling technique based on the order of the population members who have been given serial numbers.

In determining the control class and the experimental class, it was carried out randomly through shuffling (winarni et al., 2018). In the paper which will be used as shuffling, there is a number 1 which represents the student as an odd number and number 2 which represents an even number. The first student to take the number after shuffling will be the experimental class.

In this study, there are two variables, namely the independent variable and the dependent variable (Nugroho \& Arrosyad, 2021). The independent variable in this study is the picture and picture learning model. While the dependent variable is the skill of writing fiction stories. The picture and picture learning model is said to be an independent variable because of the variables that influence or cause the change or the emergence of the dependent variable, and the skill of writing fiction stories as the dependent variable because the variables are influenced or are the result, because of the independent variables.

Data collection techniques used in this study were interviews, documentation, and tests (Junanto, 2016). Interviews were conducted with class teachers to obtain data or information about conditions at SDN Sukasari such as: student characteristics, school situations, and student skills in writing fictional stories in Indonesian language learning. Meanwhile, documentation is carried out to collect data or information, either in the form of writing or pictures. This was done as additional evidence in data collection. In collecting test data, the tests used were the pretest and posttest skills in writing fiction stories. This test is done at the beginning or before being given the treatment or pretest. The same thing was done at the posttest or after being treated. The test was carried out individually on both study samples with the same question instructions. The results of this test will be compared between the experimental group and the control group for analysis. In testing the validity is done by asking for the consideration of experts (experts) in the field of evaluation or experts in the field being tested. As for the experts who were asked to assess the instruments of the researchers, namely: Anggia Suci Pratiwi, M.Pd as an Indonesian language lecturer, and Leni, S.Pd, always a grade IV teacher at SDN Sukasari. In determining the level of validity of the criteria for the assessment of writing skills, Pearson's produc moment correlation is used.

Basically, quantitative data analysis uses a statistical approach. According to (Huang, 2007 ) in statistical data analysis techniques, there are two types of statistics used, namely descriptive and inferential statistics. In this study too, researchers used descriptive statistics. 


\section{RESEARCH RESULT}

The study, entitled The Effect of the Picture and Picture Learning Model on the Skills of Writing Fiction Stories in Class IV SDN Sukasari Students began to be carried out on August 6, 2020 to August 11, 2020. The results of the research carried out were as seen in Table 1.

Table 1 Criteria validity test results writing skills assessment

\begin{tabular}{|c|c|}
\hline Cronbach's & NT of Itom \\
\hline 824 & 2 \\
\hline
\end{tabular}

The validi the test was carried out using SPSS 16, in table 1 it can be seen the values of V1 (Validator 1) and V2 (Validator 2) where the first validator is an Indonesian lecturer and the second validator is a grade IV teacher at SDN Sukasari getting results, namely 0.913 and 0.896. All $r$ counts from all criteria for writing fiction, the result is more than $r$ table $(0.878)$. This can be declared valid because the values of V1 and V2 are greater than the value of $\mathrm{r}$ table, namely 0.878 .

The technique of determining reliability in this study is using SPSS 16 by calculating the alpha coefficient. Table 2 shows the results of calculations using SPSS 16.

Table 2 Reliability statistics

\begin{tabular}{|c|c|c|c|c|}
\hline \multicolumn{5}{|c|}{ Correlations } \\
\hline \multirow{4}{*}{ V1 } & & V1 & V2 & JUMLAH \\
\hline & Pearson Correlation & 1 & .764 & $.913^{*}$ \\
\hline & Sig. (2-tailed) & & .133 & .030 \\
\hline & $\mathrm{N}$ & 5 & 5 & 5 \\
\hline \multirow[t]{3}{*}{$\mathrm{V} 2$} & Pearson Correlation & .764 & 1 & $.896^{*}$ \\
\hline & Sig. (2-tailed) & .133 & & .039 \\
\hline & $\mathrm{N}$ & 5 & 5 & 5 \\
\hline \multirow[t]{3}{*}{ Amount } & Pearson Correlation & .913 & $.896^{*}$ & 1 \\
\hline & Sig. (2-tailed) & .030 & .039 & \\
\hline & $\mathrm{N}$ & 5 & 5 & 5 \\
\hline
\end{tabular}

Table 3 Frequency Distribution of Experimental Class Pretest

Frequency 
Tia Maryani, Yopa Taufik Saleh, Rahmat Permana/Cendekiawan Vol 3 (No. 1) (2021)

\begin{tabular}{ccc}
\hline Valid & 25 & 1 \\
& 28 & 2 \\
31 & 1 \\
& 35 & 1 \\
40 & 1 \\
43 & 1 \\
45 & 1 \\
46 & 1 \\
47 & 2 \\
50 & 1 \\
54 & 1 \\
57 & 1 \\
58 & 1 \\
60 & 1 \\
61 & 3 \\
& Total & 19 \\
\hline
\end{tabular}

In table 3 the frequ frequency distribution of the pretest scores for the experimental class shows that 1 person gets a score of 25,2 people get a score of 28,1 person gets a score of 31,1 person gets a score of 35,1 person gets a score of 40,43 points 1 person, value 451 person, the value of 461 person, the value of 472 people, the value of 501 person, the value of 541 person, the value of 571 person, the value of 58 is 1 person, the value of 60 is 1 person, and the value of 61 is 3 people. The results is shown in Table 4.

Table 4 Frequency Distribution of Control Class Pretest

\begin{tabular}{ccc}
\hline \multirow{4}{*}{ Valid } & & Frequency \\
& 28 & 1 \\
& 32 & 1 \\
& 39 & 1 \\
& 40 & 1 \\
& 43 & 1 \\
& 46 & 1 \\
& 47 & 1 \\
& 49 & 1 \\
& 50 & 2 \\
& 53 & 1 \\
& 54 & 4 \\
& 60 & 1 \\
Missing & System & 1 \\
\hline & 61 &
\end{tabular}




Total 19

In table 4 it can be seen that the frequency distribution of control class pretest of the pretest scores from the control class who got a score of 28 was 1 person, a value of 32 was 1 person, a value of 39 was 1 person, a value of 40 was 1 person, a value of 43 was 1 person, a value of 46 was 1 person, the value of 47 was 1 person, the value of 49 was 1 person, the value of 50 was 2 people, the value of 53 was 1 person, the value of 54 was 4 people, the value of 60 was 1 person, and the value of 61 was 2 people.

After the pretest was carried out and given the treatment four times to the experimental class and control class students, then a posttest was carried out on the experimental class and control class students to see the learning outcomes.

The posttest data from the experimental class and control class that have been processed using SPSS 16 are as follows. The results is shown in Table 5.

Table 5 Frequency Distribution of Experimental Class Posttests

\begin{tabular}{ccc}
\hline & & Frequency \\
\hline Vali & 75 & 3 \\
$\mathrm{~d}$ & 76 & 1 \\
& 79 & 3 \\
& 80 & 2 \\
& 82 & 3 \\
& 83 & 2 \\
& 86 & 1 \\
& 90 & 2 \\
& 93 & 2 \\
& Total & 19 \\
\hline
\end{tabular}

In table 5 it can be seen that the frequency distribution of the postest scores of the experimental class who got a score of 75 is 3 people, the value of 76 is 1 person, the value of 79 is 3 people, the value of 80 is 2 people, 3 people scored 82, 2 people scored 83 , 1 person scored 86, 2 people scored 90, and 2 people scored 93. The results is shown in Table 6. 


\begin{tabular}{lcc}
\hline & & Frequency \\
\hline Valid & 68 & 1 \\
& 72 & 5 \\
& 75 & 4 \\
& 76 & 2 \\
& 79 & 2 \\
& 82 & 4 \\
& Total & 18 \\
Missing & System & 1 \\
Total & & 19 \\
\hline
\end{tabular}

In table 6 , the frequency distribution of the scores from the control class posttest that got a score of 68 was 1 person, a value of 72 was 5 people, a score of 75 was 4 people, a score of 76 was 2 people, score of 79 was 2 people, and a value of 82 was 4 people.

The normality test is useful for determining the data that has been collected is normally distributed or not. In this study, the normality test used the SPSS 16 Shapiro-Wilk method with the provision of decision making if the significance level was $>0.05$, it could be said that the data were normally distributed. The results of the normality test using SPSS 16 can be seen in the following table 7 :

Table 7 Normality test

\begin{tabular}{llccc}
\hline & \multicolumn{1}{c}{ Shapiro-Wilk } \\
\hline Skills & $\begin{array}{c}\text { Statis } \\
\text { tic }\end{array}$ & df & Sig. \\
\hline & $\begin{array}{l}\text { Pretest } \\
\text { Experiment } \\
\text { Posttest } \\
\begin{array}{l}\text { Experiment } \\
\text { Pretest }\end{array}\end{array}$ & .915 & 19 & .091 \\
$\begin{array}{l}\text { Control } \\
\text { Posttest } \\
\text { Control }\end{array}$ & .905 & 19 & .061 \\
\hline
\end{tabular}

In table 7 normality test can be seen that the data has a significance value $>0.05$. The significance value obtained from the pretest value of the experimental class is $0.091>0.05$ and the postest value of the experimental class is $0.061>0.05$. While the significance value obtained from the control class pretest value is $0.233>0.05$ and the control class postest value is $0.073>0.05$.

Thus, it can be said that the data in the study, both the experimental class and the control class, were normally distributed.

The homogeneity test is carried out to determine whether the data is homogeneous or heterogeneous. The homogeneity test in this study used the $\mathrm{f}$ count test, namely by comparing the variance of data from the two groups and the rules of decision making. According to 
(Jakni, 2016: 257) if $\mathrm{Fh}<\mathrm{Ft}$, then it is homogeneous and if $\mathrm{Fh}>\mathrm{Ft}$, then it is not homogeneous.

The results of the homogeneity test in this study can be seen in Table 8 Homogeneity of the experimental and control class pretest:

Table 8 Homogeneity of the experimental and control class pretest

\begin{tabular}{|c|c|}
\hline \multicolumn{2}{|l|}{ Pretest } \\
\hline Variance & 149.9181287 \\
\hline Experiment & \\
\hline Variance of Pretest Control & 87.31045752 \\
\hline F count & 1.717069558 \\
\hline $\mathrm{db}$ numerator $=\mathrm{n}-1$ & 18 \\
\hline $\mathrm{db}=\mathrm{n}-1$ & 17 \\
\hline Significance Level & 0,05 \\
\hline F table & 2,26 \\
\hline Conclusion & Homogen \\
\hline
\end{tabular}

In table 8 , it can be seen that the value of $\mathrm{f}$ pretest data count $<$ from $\mathrm{f}$ table is 1.71 $<2.26$. So it can be said that the results of this study are homogeneous.

Table 9 Homogeneity of Posttest Classes of Experiment and Control

\begin{tabular}{ll}
\hline \multicolumn{1}{c}{ Posttest } \\
\hline Posttest Variance Experiment & 33.61988304 \\
Posttest Control Variance & 18.22222222 \\
& \\
F count & 1.844993582 \\
$\mathrm{db}$ numerator $=\mathrm{n}-1$ & 18 \\
$\mathrm{db}=\mathrm{n}-1$ & 17 \\
Significance Level & 0,05 \\
$\mathrm{~F}$ table & 2,26 \\
Conclusion & Homogen \\
\hline
\end{tabular}

In 9 , it can be seen that the value of $\mathrm{f}$ pretest data count $<$ from $\mathrm{f}$ table, namely $1.84<$ 2.26. So it can be concluded that this research is homogeneous and in accordance with the rules of decision making.

Hypothesis testing in this study is using the independent sample test (t test) (Kpk \& Material, 2020). The $t$ test was used to compare the mean of the two groups of data obtained from one group of research subjects with data with an interval scale. table 10:

The following are the results of the $t$ test using SPSS 16 can be seen in the following

Table 10 Independent samples test

\begin{tabular}{cccccc}
\hline & $\mathbf{F}$ & Sig. & $\mathbf{T}$ & $\mathbf{d f}$ & $\begin{array}{c}\text { Sig. }(2- \\
\text { tailed) }\end{array}$ \\
$\begin{array}{c}\text { Equal variances } \\
\text { assumed }\end{array}$ & 9.756 & .004 & -11.600 & 36 & .000 \\
$\begin{array}{c}\text { Equal variances } \\
\text { not assumed }\end{array}$ & & & -11.600 & 25.687 & .000 \\
\hline
\end{tabular}


In table 10 it can be seen that the calculation on the difference test in the average value of writing skills for fourth grade students of SDN Sukasari can be assessed by the decision rule if the value is significance or sig. (2-tailed) $>0.05$ then Ho is accepted and $\mathrm{Ha}$ is rejected, whereas if the value is significant or sig. (2-tailed) $<0.05$ then $\mathrm{Ho}$ is rejected and $\mathrm{Ha}$ is accepted.

From the table of the results of the Independent Sample Test, the significance value is 0.000. In accordance with the rules of decision making, $0.000<0.05$, it can be concluded that $\mathrm{Ho}$ is rejected and $\mathrm{Ha}$ is accepted. This means that the picture and picture learning model affects the skills of writing fiction stories in fourth grade students of SDN Sukasari.

\section{DISCUSSION}

The study, entitled The effect of picture and picture learning media on the skills of writing fiction stories in the fourth grade students of SDN Sukasari, was conducted on all grade IV students, totaling 37 students. Students were divided into two groups, namely the experimental class group totaling 19 students and the control class group totaling 18 students. The research was conducted in three stages, namely pretest, treatment, and posttest.

In the pretest activity the experimental class got an average score of 46.16 and the control class got an average score of 48.61. Whereas in the posttest the experimental class got an average score of 82.21 and the control class got an average score of 75.89 . This proves that after using the picture and picture learning model in the experimental class treatment, it has a positive effect on story writing skills (Hidayat, 2017).

(Lies Aryanti Nur Sholekah \& Agus Nuryatim, 2017) argue that the picture and picture model is a learning model that uses images and is paired or sorted into a logical sequence. This learning model relies on images as a medium in the learning process. In addition, image media can also be used to explain a material or facilitate students to actively learn.

The same thing was stated by (Eko et al., 2019) picture and picture is a learning model using pictures and paired or ordered into a logical sequence. This learning model relies on images which are the main factors in the learning process.

The role of the learning model is very important to support student learning. According to (Wuryani \& Yamtinah, 2018) the learning model is a form of learning that is described from beginning to end which is typically presented by the classroom teacher. In the learning model, there is a strategy to achieve the competence of students with a method approach and learning techniques. (Atmazaki, 2018) also argues that the learning model is a method/presentation technique used by teachers in the learning process in order to achieve learning objectives. The learning model has a very important role in learning, because through choosing the right model it can lead teachers to the quality of effective learning.

Story writing skills can be continuously trained and honed, using appropriate and varied learning models will help students to develop ideas and ideas so that students become more skilled in writing. According to (Lies Aryanti Nur Sholekah \& Agus Nuryatim, 2017) writing skills are language skills used in indirect communication. Writing skills in Indonesian language learning are very important in the world of education, because it makes it easier for students to think.

Meanwhile, according to (Ai Parihah, M. Fahmi Nugraha, 2020) writing skills are the most complex language skills. This is because the ability to write is a process in language activities.

Writing skills are also closely related to language skills, according to (Cahyono, 2006) language skills are one of the skills students must have because they support them in mastering other skills. If the student is able to speak the language, he will more easily receive new information or knowledge.

There are three stages of the writing process according to (Wuryani \& Yamtinah, 2018), namely: (1) the pre-writing stage, (2) the writing stage, and (3) the revision or improvement 
stage. To implement these three stages, in language education, especially writing skills, it is necessary to integrate the writing process and product in the classroom. This really depends on the learner's interest in writing, cooperation between learners, the opportunity or the establishment of teaching and learning models for writing.

The results of this study have been processed using SPSS 16. Based on the results obtained on the independent sample t-test, it gets a sig value of 2 -tailed) 0.000 , which means that there is a significant effect. If the significant value is smaller than the significance level $<0.05$, then $\mathrm{Ho}$ is rejected and $\mathrm{Ha}$ is accepted. The picture and picture learning model has a positive influence on the skills of writing fiction stories.

\section{CONCLUSION}

Based on the results of research and data processing that has been carried out by researchers, it can be said that the picture and picture learning model affects the skills of writing fiction stories in fourth grade students of SD Negeri Sukasari.

This can be seen in the results of the pretest and posttest in the experimental class and the control class. The minimum score obtained in the experimental class is 25 and the maximum value is 61 . Meanwhile, the minimum score obtained by the control class is 28 and the maximum value is 61 . However, after treatment in the experimental class using the picture and picture learning model, the minimum score obtained is 75 and the maximum value is 93 . Meanwhile, the control class that does not use the picture and picture learning model gets a minimum score of 68 while the maximum score is 82 . In addition, the results of hypothesis testing obtained a significance value of $0.000<0.05$. So this is in accordance with the rules of decision making because $0.000<0.05$. Therefore, it can be concluded that Ho is rejected and $\mathrm{Ha}$ is accepted. This means that the picture and picture learning model affects the skills of writing fiction stories in fourth grade students of SDN Sukasari.

\section{REFERENCE}

Ai Parihah, M. Fahmi Nugraha, A. S. P. (2020). The Effect of the Chain Writing Method on the Writing Skills of Class V Elementary School Students. Cendekiawan, 2(2), 83-87. Cendekiawan.unmuhbabel.ac.id

Arifian, F. D. (2018). Sketsa Konsep Literasi Modern. 30 Jurnal Pendidikan Dan Kebudayaan Missio, 10(10), 27-38.

Atmazaki. (2018). Text-Based Indonesian Learning. Jurnal Ilmiah Kebudayaan Sintesis, 11(1), 111.

Cahyono, B. Y. (2006). the Teaching of Efl Reading in the Indonesian Context: the State of the Art. The Teaching of Efl Reading in the Indonesian Context: The State of the Art, 17(1), 3658. https://doi.org/10.15639/teflinjournal.v17i1/37-60

Eko, Y., Utomo, P., Nugroho, A. S., \& Listyarini, I. (2019). Application of the Picture and Picture Model to the Ability to Write an Essay. E-Journal PGSD Mimbar PGSD, 7(2), 4956.

Hidayat, R. (2017). The Effect of Picture and Picture Learning Model on the Ability to Write Essay Descriptions of Class VII Students of SMP Nurul Azman Gunung Putri Bogor. Deiksis, 9(03), 385. https://doi.org/10.30998/deiksis.v9i03.953

Huang, J. (2007). A Technical Study of A Painting by Suzuki Harunobu at the Museum of Fine Arts, Boston: artist's palette and techniques. The Book and Paper Group Annual, 26, 151-153. 
Jakni. (2016). Experimental Research Methodology in Education. Bandung: Alfabeta.

Junanto, S. (2016). Evaluation of the Integral Muslim Personality Development Assistance Program (P3Kmi) in the Department of Teacher Education Raudhatul Athfal Faculty of Tarbiyah and Other Teacher Training Surakarta in 2016. Jurnal Penelitian, 10(2), 423-440. https://doi.org/10.21043/jupe.v10i2.1780

Kpk, F. P. B., \& Material, K. P. K. (2020). The Influence of Dakota Media and Activeness on Student Achievement in. Cendekiawan, 2(2), 95-103.

Lies Aryanti Nur Sholekah \& Agus Nuryatim. (2017). Indonesian language and literature education. Jurnal Pendidikan Bahasa Dan Sastra Indonesia, 1(budaya literasi dalam pembelajaran bahasa), 12-16. https://journal.unnes.ac.id/sju/index.php/jpbsi/article/view/20226

Lin, M. H., Chen, H. C., \& Liu, K. S. (2017). A study of the effects of digital learning on learning motivation and learning outcome. Eurasia Journal of Mathematics, Science and Technology Education, 13(7), 3553-3564. https://doi.org/10.12973/eurasia.2017.00744a

Natsir, M. (2018). Spiritual education through learning al mahfudzot (Arabic aphorisms). Tarbawi : Jurnal Pendidikan Islam, 15(2). https://doi.org/10.34001/tarbawi.v15i2.848

Ngobolo, E. N., Ruparaganda, F., Mukundu, C. K., \& Munjoma, G. (2012). Factors affecting ICT Policy Implementation in Rural Namibian Schools. Zimbabwe Journal of Educational Research, 24(3), 224-243.

Nugroho, F., \& Arrosyad, M. I. (2021). the Implementation Blended Learning Method Using Articulated Storyline in Class 4 Fraction Learning, Muhammadiyah Primary School, Pangkalpinang. Berumpun: International Journal of Social, Politics, and Humanities, 4(1), 40-47. https://doi.org/10.33019/berumpun.v4i1.46

Ocampo, M. C. B., \& Delgado, P. I. (2014). Basic Education and Cultural Heritage: Prospects and Challenges. International Journal of Humanities and Social Science, 4(9), 201-209.

Pratidana, D. (2017). Reduced Specificity of Autobiographical Memory and Depression: The Role of Executive Control. Journal of Experimental Psychology: General, 136(1), 23-42.

Rachama Putri Dinanti, Feri Ardiansah, R. (2020). Indonesian for Grade V Elementary School Students Language Learning for Class V Elementary School Students. Cendekiawan, 2(2), 64-68. https://cendekiawan.unmuhbabel.ac.id/index.php/CENDEKIAWAN

Sugiono. (2015). Analysis of Provision and Use of MSME Working Capital (Micro, Small and Medium Enterprises) in Increasing Operating Profits at Alam Lestari KUB (Joint Business Group) Depok. Prosiding Semiar Nasional Pendidikan Ekonomi \& Bisnis.

Syarif, E. (2020). Improving Short Story Writing Skills Using Pop Up Media for Class V Students Sdn 36 Sungai Ambawang. (J-PSH) Jumal Pendidikan Sosiologi Dan Humaniora, 11(1), 20-24.

Widiastuti, A. (2017). Application of Contextual Approach to Improve Essay Writing Skills of Grade IV Elementary School Students. Jurnal Pendidikan Guru Sekolah Dasar, 2(3), 52 64. https://doi.org/10.17509/jpgsd.v2i3.13266

Winarni, E. W., Purwandari, E. P., Lusa, H., \& Dadi, S. (2018). The Impact of Thematic 
Tia Maryani, Yopa Taufik Saleh, Rahmat Permana/Cendekiawan Vol 3 (No. 1) (2021)

Learning Integrated ICT in Tabot Bengkulu as Cultural Ceremony toward Social Interaction Knowledge in Elementary School. Asian Journal of Education and Training, 4(2), 70-74. https://doi.org/10.20448/journal.522.2018.42.70.74

Wuryani, M. T., \& Yamtinah, S. (2018). Textbooks Thematic Based Character Education on Thematic Learning Primary School: An Influence. International Journal of Educational Methodology, 4(2), 75-81. https://doi.org/10.12973/ijem.4.2.75 